\title{
Gene Transfer of a Human Insulin-Like Growth Factor I cDNA Enhances Tissue Engineering of Cartilage
}

\author{
HENNING MADRY, ${ }^{1-3}$ ROBERT PADERA, ${ }^{2}$ JOACHIM SEIDEL, ${ }^{2}$ ROBERT LANGER, ${ }^{2}$ LISA E. FREED ${ }^{2}$ \\ STEPHEN B. TRIPPEL, ${ }^{1,4}$ and GORDANA VUNJAK-NOVAKOVIC ${ }^{2}$
}

\begin{abstract}
The repair of articular cartilage lesions remains a clinical problem. Two novel approaches to cartilage formation, gene transfer and tissue engineering, have been limited by short-term transgene expression in transplanted chondrocytes and inability to deliver regulatory signals to engineered tissues according to specific temporal and spatial patterns. We tested the hypothesis that the transfer of a cDNA encoding the human insulin-like growth factor I (IGF-I) can provide sustained gene expression in cell-polymer constructs in vitro and in vivo and enhance the structural and functional properties of tissue-engineered cartilage. Bovine articular chondrocytes genetically modified to overexpress human IGF-I were seeded into polymer scaffolds, cultured in bioreactors in serum-free medium, and implanted subcutaneously in nude mice; constructs based on nontransfected or lacZ-transfected chondrocytes served as controls. Transgene expression was maintained throughout the duration of the study, more than 4 weeks in vitro followed by an additional 10 days either in vitro or in vivo. Chondrogenesis progressed toward the formation of cartilaginous tissue that was characterized by the presence of glycosaminoglycans, aggrecan, and type II collagen, and the absence of type I collagen. IGF-I constructs contained increased amounts of glycosaminoglycans and collagen and confined-compression equilibrium moduli as compared with controls; all groups had subnormal cellularity. The amounts of glycosaminoglycans and collagen per unit DNA in IGF-I constructs were markedly higher than in constructs cultured in serum-supplemented medium or native cartilage. This enhancement of chondrogenesis by spatially defined overexpression of human IGF-I suggests that cartilage tissue engineering based on genetically modified chondrocytes may be advantageous as compared with either gene transfer or tissue engineering alone.
\end{abstract}

\section{OVERVIEW SUMMARY}

The objective of the present study was to use sustained expression of a gene, the product of which has anabolic effects, in a model system of cartilage tissue engineering. We report experimental evidence supporting the hypothesis that spatially defined overexpression of a human IGF-I cDNA in articular chondrocytes can enhance chondrogenesis and improve the structural and functional properties of tissueengineered cartilage. Genetically modified cartilaginous constructs may be applied for the repair of articular carti- lage lesions and for controlled studies of factors and mechanisms involved in the regulation of chondrogenesis.

\section{INTRODUCTION}

$\mathbf{T}$ HE INTRINSIC REPAIR of damaged articular cartilage is minimal. Although a variety of methods currently exist to repair cartilage lesions, none of them has been shown to predictably restore a durable articular surface (Buckwalter and Mankin, 1998). The clinical need for improved treatment op-

\footnotetext{
${ }^{1}$ Orthopedic Research Laboratories, Department of Orthopedic Surgery, Harvard Medical School, Massachusetts General Hospital, Boston, MA 02114

${ }^{2}$ Harvard-MIT Division of Health Sciences and Technology, Massachusetts Institute of Technology, Cambridge, MA 02139.

${ }^{3}$ Present address: Laboratory for Experimental Orthopedics, Department of Orthopedic Surgery, Saarland University, D-66421 Homburg, Ger-

${ }^{4}$ Present address: Department of Orthopedic Surgery, Indiana University School of Medicine, Indianapolis, IN 46202.
} many. 
tions is being addressed by gene therapy (Evans and Robbins, 1999) and tissue engineering (Langer and Vacanti, 1993). These two different approaches have each led to encouraging initial results (Langer and Vacanti, 1993; Baragi et al., 1995; Kang et al., 1997; Doherty et al., 1998; Evans and Robbins, 1999; Madry and Trippel, 2000). Both approaches are also subject to limitations, including short-term expression of transgenes in articular chondrocytes (Baragi et al., 1995; Kang et al., 1997; Doherty et al., 1998; Madry and Trippel, 2000) and the inability to deliver regulatory signals to cells in engineered tissues according to specific temporal and spatial patterns (Saltzman, 1999).

Functional substitutes of native articular cartilage can be created in vitro starting from chondrogenic cells attached to polymer scaffolds in bioreactors, herein referred to as cartilaginous cell-polymer constructs (Freed and Vunjak-Novakovic, 2000). During this process, chondrocytes produce extracellular tissue matrix consisting of proteoglycans and type II collagen in parallel with the scaffold degradation (Freed et al., 1998). The resulting cartilaginous constructs are generally characterized by subnormal structural and mechanical properties. For example, after 6 weeks of culture cell-polymer constructs contain $75 \%$ as much glycosaminoglycan and $40 \%$ as much collagen, and have a confined-compression equilibrium modulus that is 4-fold lower as compared with freshly explanted articular cartilage (Vunjak-Novakovic et al., 1999).

Insulin-like growth factor I (IGF-I), a 7.6-kDa polypeptide growth factor, has been shown to increase chondrocyte mitotic activity and proteoglycan and type II collagen synthesis in vitro (Trippel, 1997). It has been demonstrated that articular chondrocytes can be genetically modified (Baragi et al., 1995; Kang et al., 1997; Doherty et al., 1998; Madry and Trippel, 2000) to express recombinant IGF-I (Madry and Trippel, 2000; Smith et al., 2000; Brower-Toland et al., 2001). Overexpression of human IGF-I stimulated synthesis of collagen and noncollagenous proteins in chondrocytes in vitro (Smith et al., 2000; BrowerToland et al., 2001), and promoted new tissue formation in an ex vivo model of articular chondrocyte transplantation (Madry et al., 2001b). It remains unknown whether the chondrogenesis in tissue-engineered cartilaginous constructs can be modulated by localized overexpression of human IGF-I.

In the present work, we tested the hypothesis that transgene expression in genetically modified cartilaginous constructs is maintained in vitro and after subcutaneous implantation in vivo, and that the transfer of a human IGF-I cDNA augments the structural and functional properties of tissue-engineered cartilage.

\section{MATERIALS AND METHODS}

\section{Model system}

We engineered cartilaginous constructs by using bovine articular chondrocytes that were (1) not modified (referred to as nontransfected constructs), (2) genetically modified to overexpress the Escherichia coli $\beta$-galactosidase (lacZ) gene (referred to as lacZ constructs), or (3) genetically modified to overexpress a human insulin-like growth factor I cDNA (referred to as IGF-I constructs). These three groups of chondrocytes were seeded onto biodegradable polymer scaffolds and cultured in bioreactors in serum-free medium. The resulting constructs were harvested after 10,21, 28, and 38 days for structural and functional assessment. After 28 days of cultivation, constructs from each group were implanted subcutaneously in nude mice for 10 days to verify the maintenance of gene expression in vivo (Fig. 1).

\section{Plasmid expression vectors}

For overexpression of IGF-I, the human IGF-I plasmid expression vector pCMVhIGF-I was used. Bovine articular chondrocytes transfected with pCMVhIGF-I secrete significant levels of bioactive human IGF-I protein (Madry et al., 2001b). For expression of $\beta$-galactosidase, the plasmid expression vector pCMVSport $\beta$ Gal (GIBCO-Life Technologies, Grand Island, NY) was applied. Plasmids were subjected to endotoxin-free maxipreparation (Qiagen, Hilden, Germany).

\section{Cell culture, transfection, and seeding onto scaffolds}

Chondrocytes were obtained from articular cartilage harvested from radiocarpal joints of 1 - to 2 -week-old calves (Trippel et al., 1983). In each experiment, chondrocytes were isolated from pooled cartilage harvests from four to eight radiocarpal joints, and placed in monolayer culture in growth medium (Dulbecco's modified Eagle's medium [DMEM] with ascorbic acid [50 $\mu \mathrm{g} / \mathrm{ml}$ ], penicillin $\mathrm{G}$ [100 U/ml], and streptomycin $[100 \mu \mathrm{l} / \mathrm{ml}]$ supplemented with $10 \%$ calf serum) (GIBCO-Life Technologies) at $37^{\circ} \mathrm{C}$ in a humidified atmosphere with $10 \% \mathrm{CO}_{2}$. Chondrocytes were transfected after 2-3 days in culture, using the nonliposomal lipid preparation FuGENE 6 (Roche, Mannheim, Germany) with either pCMVhIGF-I (IGF-I group), pCMVSport $\beta$ Gal (lac $Z$ group), or no vector (nontransfected group), and exposed to bovine testicular hyaluronidase $(4 \mathrm{U} / \mathrm{ml}) 12 \mathrm{hr}$ before and during transfection (Madry and Trippel, 2000).

One day after transfection, chondrocytes were dissociated from the culture plates, suspended in growth medium, and dynamically seeded onto polyglycolic acid scaffolds $(5 \times 2 \mathrm{~mm}$ fibrous disks, $5 \times 10^{6}$ cells per scaffold) as previously described (Vunjak-Novakovic et al., 1998). Aliquots of the cell preparations that were used for seeding of the cell-polymer constructs were subjected to 5-bromo-4-chloro-3-indolyl- $\beta$-Dgalactopyranoside (X-Gal) staining to assess the success of the transfection. The number of X-Gal-positive cells was between 25 and $40 \%$ on the basis of X-Gal staining of lacZ-transfected chondrocytes, consistent with a previous study using the same technique (Madry and Trippel, 2000).

After 2 days, cell-polymer constructs were transferred into bioreactors. Rotating bioreactors were used (RCCV-110; Synthecon, Houston, TX) and were configured as an annular space between a 57.5-mm-diameter outer cylinder and a 20-mm-diameter inner gas exchange membrane that rotates as a solid body around its horizontal axis (Freed et al., 1998). The vessel-rotating rate is adjusted such that each tissue construct is freely suspended in the rotational flow (Freed and Vunjak-Novakovic, 2000). Over the course of tissue cultivation, the increase in construct size and weight necessitated a gradual increase in the rotation rate from 15 to $30 \mathrm{rpm}$ in order to keep the growing constructs freely suspended. Constructs $(n=12$ per vessel) were cultured in $120 \mathrm{ml}$ of basal medium (DMEM 


\section{Transfection}
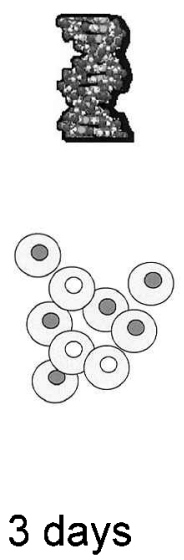

Seeding

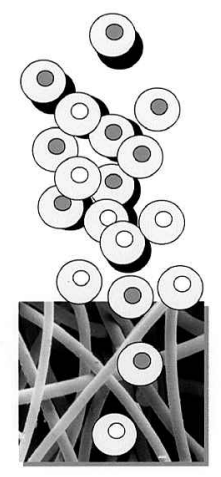

Bioreactor cultivation

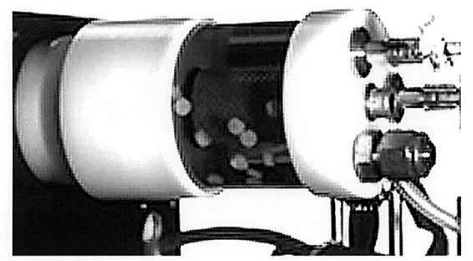

\section{Implantation}

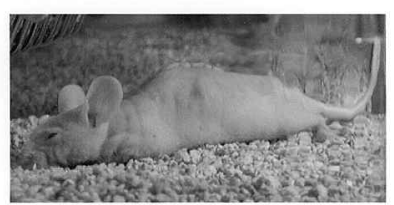

FIG. 1. Model system. Chondrocytes were isolated from the articular surface of bovine radiocarpal joints, placed in monolayer culture, and transfected after 3-4 days with a lipid-based system. After 1 day, transfected chondrocytes were dissociated from the culture vessel and dynamically seeded onto biodegradable polymer scaffolds. After 2 days, the seeded constructs were transferred to rotating bioreactors and cultured for 28 days in basal medium, followed by an additional 10 days in vivo (in nude mice) or in vitro (in bioreactors).

with ascorbic acid $[50 \mu \mathrm{g} / \mathrm{ml}]$, penicillin $\mathrm{G}[100 \mathrm{U} / \mathrm{ml}]$, and streptomycin [100 $\mu \mathrm{l} / \mathrm{ml}]$ ) and sampled on days $10,21,28$, and 38 posttransfection. Medium was replaced every 3 days (50\%); gas exchange was continuous.

\section{RNA isolation and Northern analysis}

Total cellular RNA was extracted from chondrocytes in monolayer culture 8 days after transfection (RNeasy; Qiagen), fractionated on $1 \%$ agarose gels, and transferred to nylon membranes (Bio-Rad, Hercules, CA). After cross-linking of the membranes and prehybridization, RNA was hybridized for 16 hr at $42^{\circ} \mathrm{C}$ to a human IGF-I or a bovine glyceraldehyde-3phosphate dehydrogenase (GAPDH) cDNA probe labeled with $\left[{ }^{32} \mathrm{P}\right] \mathrm{dCTP}$, using a random primer labeling kit (Stratagene, La Jolla, CA). The final stringency of wash was $0.5 \times \operatorname{SSPE}(1 \times$ SSPE is $0.18 M \mathrm{NaCl}, 10 \mathrm{~m} M \mathrm{NaPO}_{4}$, and $1 \mathrm{~m} M$ EDTA [pH 7.7]) $-0.5 \%$ sodium dodecyl sulfate (SDS) at $65^{\circ} \mathrm{C}$.

\section{Histology and immunohistochemistry}

Constructs were fixed in $10 \%$ formalin for $24 \mathrm{hr}$, embedded in paraffin, cut to $5 \mu \mathrm{m}$ either en face or in cross-section, and stained with safranin $\mathrm{O}$ to detect proteoglycans. To detect $\beta$ galactosidase activity, constructs were fixed for $10 \mathrm{~min}$ in $10 \%$ formalin and stained for $4-6 \mathrm{hr}$ at $37^{\circ} \mathrm{C}$ for $\beta$-galactosidase (In Situ $\beta$-galactosidase staining kit; Stratagene) (Madry and Trippel, 2000). For immunostaining, sections were deparaffinized in xylene, passed through decreasing concentrations of ethanol, washed in phosphate-buffered saline (PBS), and submerged for $30 \mathrm{~min}$ in $0.3 \%$ hydrogen peroxide. After washing with PBS, sections were incubated for $30 \mathrm{~min}$ in bovine testicular hyaluronidase (33 U/ml; Sigma, St. Louis, MO), washed with PBS, and further incubated with $1 \%$ bovine serum albumin (blocking buffer). Sections were then incubated with a mono- clonal anti-bovine type I collagen IgG (Sigma), an anti-bovine type II collagen IgG (Developmental Studies Hybridoma Bank, Ames, IA), or a monoclonal anti-aggrecan (Serotec, Oxford, UK). The primary antibody was detected with a Vectastain Elite ABC kit (Vector Laboratories, Burlingame, CA), using diaminobenzidine as the chromogen. Positive controls included bovine articular cartilage with vascular structures (for types I and II collagen and aggrecan) and rat skin (for collagen type I). Negative controls included omission of the primary antibody, rat skin (for collagen type II and aggrecan), and bovine articular cartilage (for collagen type I).

\section{Morphometric measurements and biochemical evaluation}

Construct dimensions were measured from safranin $\mathrm{O}$ stained histological sections, using computer-based image analysis as previously described (Martin et al., 1999). Briefly, low-magnification phase-contrast images of the whole crosssections of tissue samples were acquired by a solid-state CCD camera (Hitachi, Tokyo, Japan) mounted on an inverted microscope (Diaphot; Nikon, Melville, NY), digitized by an LG3 frame grabber (Scion, Frederick, MD) into a Macintosh 7100, and analyzed with the NIH Image public domain program NIH 1.59. For biochemical evaluations, constructs were lyophilized, digested for $16 \mathrm{hr}$ at $56^{\circ} \mathrm{C}$ with protease $\mathrm{K}(1 \mathrm{mg} / \mathrm{ml}$; Sigma) solution in $50 \mathrm{~m} M$ Tris- $1 \mathrm{~m} M$ EDTA-1 $\mathrm{m} M$ iodoacetamide, using $1 \mathrm{ml}$ of enzyme solution per 4-10 mg sample dry weight (Freed et al., 1998). DNA was measured by the Hoechst 33258 assay, using a QM-1 spectrofluorometer (Photon Technology International, South Brunswick, NJ) (Kim et al., 1988). Glycosaminoglycans were measured spectrophotometrically (PerkinElmer, Norwalk, CT), using dimethylmethylene blue dye and bovine chondroitin sulfate as a standard (Serva, Darm- 
stadt, Germany) (Farndale et al., 1986). Total collagen was determined from the measured hydroxyproline content after acid hydrolysis and reaction with p-dimethylaminobenzaldehyde and choramine-T(Woessner, 1961), using a hydroxyproline-tocollagen ratio of 1:10 (Hollander et al., 1994). To determine the biosynthesis rates of protein and proteoglycan, constructs ( $n=6$ per group) were individually radiolabeled in 12-well plates, using $1 \mathrm{ml}$ of basal medium containing $\left[{ }^{3} \mathrm{H}\right]$ proline $(15-20 \mu \mathrm{Ci} / \mathrm{ml})$ and $\left[{ }^{35} \mathrm{~S}\right]$ sulfate $(7.5-25 \mu \mathrm{Ci} / \mathrm{ml}$; New England Nuclear, Boston, MA), as previously described (Freed et al., 1998). Briefly, dishes were placed on an orbital shaker and incubated for $18 \mathrm{hr}$ at $37^{\circ} \mathrm{C}$ in a humidified atmosphere with $10 \%$ $\mathrm{CO}_{2}$. Each construct was rinsed four times for $20 \mathrm{~min}$ with PBS ( $2 \mathrm{ml} /$ rinse), frozen, lyophilized, and digested with papain $(0.125 \mu \mathrm{g} / \mathrm{ml}$; Sigma) in $100 \mathrm{~m} M$ phosphate buffer with $10 \mathrm{~m} M$ EDTA and $10 \mathrm{~m} M$ cysteine for $16 \mathrm{hr}$ at $60^{\circ} \mathrm{C}$. Aliquots of 200 $\mu l$ were transferred to scintillation vials and counted in $4 \mathrm{ml}$ of Cytoscint (ICN, Costa Mesa, CA) in a $\beta$ counter (Packard Instruments, Meriden, CT).

\section{IGF-I protein analysis}

Constructs harvested from bioreactors at 10 days posttransfection were individually incubated in 24-well plates for $24 \mathrm{hr}$ in $1 \mathrm{ml}$ of basal medium. Medium collected from these dish cultures as well as medium sampled from the bioreactors were stored at $-80^{\circ} \mathrm{C}$. To determine IGF-I production, conditioned medium was subjected to a three-step acid-acid-ethanol extraction of binding proteins and analyzed by a radioimmunoassay with a detection limit of $20 \mathrm{ng} / \mathrm{ml}$ (Nichols Institute, San Juan Capistrano, CA).

\section{Biomechanical testing}

Constructs ( $n=3$ or 4 per group) were equilibrated for $1 \mathrm{hr}$ at room temperature in PBS supplemented with penicillin (100 $\mathrm{U} / \mathrm{ml})$, streptomycin $(100 \mu \mathrm{g} / \mathrm{ml})$, and proteinase inhibitors (1 $\mathrm{m} M$ phenylmethylsulfonyl fluoride, $2 \mathrm{~m} M$ disodium EDTA, 5 $\mathrm{m} M$ benzamidine- $\mathrm{HCl}, 10 \mathrm{~m} M N$-ethylmaleimide), and cored into 3-mm-diameter, 2-mm-thick disks. Each specimen was mounted in a cylindrical confining chamber connected to a servo-controlled mechanical spectrometer (Dynastat; Imass, Hingham, MA), and compressed under a porous polyethylene platen. The initial strain of $10 \%$ was sequentially increased in $5 \%$ increments up to a maximum of $35 \%$. After stress relaxation, the equilibrium stress was measured and the equilibrium modulus was determined from the slope of the linear regression fit of the stress-strain correlation (Frank and Grodzinsky, 1987; Vunjak-Novakovic et al., 1999).

\section{Subcutaneous implantation}

The animal protocol was approved by the Massachusetts Institute of Technology (Cambridge, MA) Committee on Animal Care. Constructs ( $n=6$ per group) were sampled from bioreactors 4 weeks posttransfection, implanted in dorsal subcutaneous pouches in immunocompromised mice (NIH Swiss nude, 25- to 30-g males; Taconic [Germantown, NY] or Charles River [Cambridge, MA]) and harvested after 10 days of implantation. Explants were assayed for reporter gene expression and histological appearance.

\section{Statistical analysis}

We performed four independent sets of experiments, involving a total of 125 constructs engineered with bovine articular chondrocytes obtained from 26 radiocarpal joints. Data are expressed as averages \pm SD and were analyzed by two-way analysis of variance (ANOVA). A two-tailed $p<0.05$ was considered statistically significant.

\section{RESULTS}

\section{Northern analysis of transfected bovine articular chondrocytes}

Northern hybridization with a human IGF-I DNA probe of total cellular RNA isolated from chondrocytes transfected with the IGF-I plasmid expression vector ( $\mathrm{pCMVhIGF-I)} \mathrm{revealed} \mathrm{a}$ broad band spanning a range of $\sim 1.2$ to $1.6 \mathrm{~kb}$. These transcripts were not detectable in RNA from lacZ-transfected chondrocytes. The transcripts likely represent two mRNA populations of $\sim 1.3$ and $1.5 \mathrm{~kb}$ generated by the alternative usage of the two polyadenylation sites present in the construct, both of which are translated to the same mature IGF-I polypeptide (Fig. 2) (Eming et al., 1996).

\section{Transgene expression and chondrogenesis}

To determine the level of recombinant IGF-I protein production, conditioned medium produced by the transfection of monolayers of bovine articular chondrocytes with pCMVhIGFI was analyzed by IGF-I radioimmunoassay. Mean IGF-I production was approximately $80 \mathrm{ng}$ per $1 \times 10^{7}$ cells, consistent with our previous studies $\left(83 \pm 22 \mathrm{ng}\right.$ per $1 \times 10^{7}$ cells; Madry

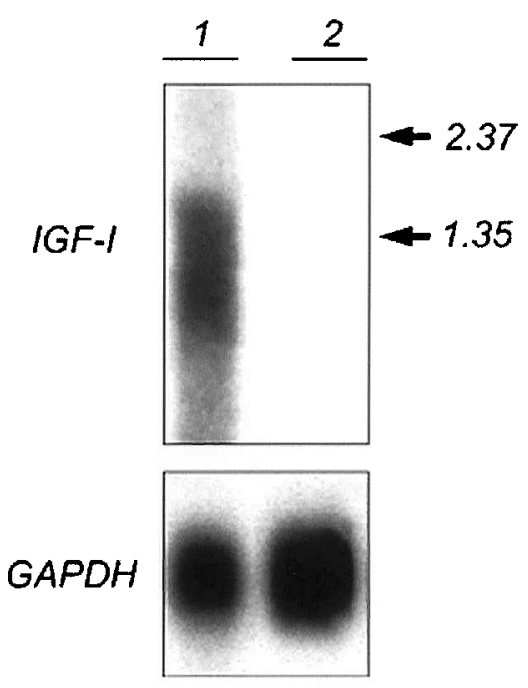

FIG. 2. Northern analysis. Total cellular RNA from chondrocytes transfected with the hIGF-I expression plasmid vector (lane 1) and with the $l a c Z$ expression plasmid vector (lane 2) was hybridized to a DNA probe corresponding to the hIGF-I cDNA in the transgene and subsequently rehybridized to a bovine GAPDH DNA probe. The positions of the 2.37- and $1.35-\mathrm{kb}$ RNA markers are indicated by arrows. 

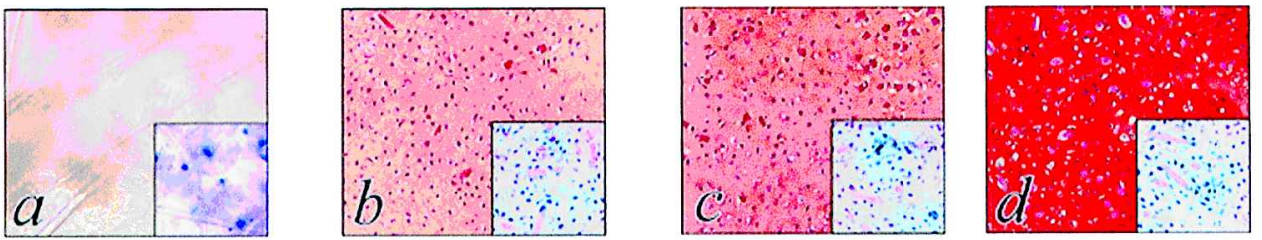

FIG. 3. Transgene expression and progression of chondrogenesis. (a) Cell-polymer constructs 2 days after seeding, (b) constructs cultured for 28 days, (c) constructs cultured for 38 days, and (d) constructs cultured for 28 days and implanted in nude mice for 10 days, all from the IGF-I group, stained with safranin O. Insets show the corresponding lacZ constructs, stained with $\mathrm{X}-\mathrm{Gal}$. Original magnification (all images and insets): $\times 200$.

et al., 2001b). Transgene expression, determined by X-Gal staining of lac $Z$ constructs, was maintained over 28 days in vitro followed by 10 more days either in vitro or in vivo. X-Gal-positive cells were distributed throughout the constructs until the end point of this study (day 38) (insets, Fig. 3a-d). The corresponding intensity and uniformity of distribution of safranin $\mathrm{O}$ stain in constructs based on IGF-I-transfected chondrocytes progressively increased over the period of bioreactor culture (Fig. $3 \mathrm{a}-\mathrm{c}$ ), and continued to increase over 10 days of in vivo implantation (Fig. 3b and d). Explanted constructs appeared cartilaginous over their entire cross-sections, and were surrounded only by a thin fibrous capsule characteristic for subcutaneous implantation (data not shown). The intensity of safranin O staining was higher after 28 days of in vitro culture followed by 10 days in vivo (Fig. 3d) than after 38 days in vitro (Fig. 3c).

\section{Structure and composition of engineered cartilaginous constructs}

After dissociation from the cell culture dish, chondrocyte viability was above $90 \%$ for all groups (data not shown). The fractions of chondrocytes that attached to the scaffolds were compa- rable for the nontransfected, lacZ, and IGF-I constructs (80.8 \pm $8.2,78.0 \pm 9.8$, and 77.6 $\pm 8.0 \%$, respectively; $n=3, p>0.05)$. There was no difference in the postseeding cell viability $(94.9 \pm$ $2.4,95.2 \pm 3.4$, and $94.8 \pm 1.2 \%$, respectively, $n=3, p>0.05$ ), suggesting that the transfection procedure and transgene products had no adverse effect on chondrocyte viability and attachment.

Over the course of bioreactor culture, the initial wet weight $(78 \pm 14 \mathrm{mg})$ and size $(5 \mathrm{~mm}$ in diameter $\times 2 \mathrm{~mm}$ thick $)$ of nontransfected and lac $Z$ constructs decreased significantly and progressively. This suggests that, in these controls, tissue accumulation resulting from the biosynthetic activity of their cells was exceeded by scaffold degradation (Fig. 4a and Table 1). In contrast, the wet weight and size of IGF-I constructs were maintained throughout the period of bioreactor cultivation and after 28 days were significantly higher than for either control(Fig. 4a and Table 1). After 28 days of cultivation, transgene expression was maintained as evidenced by X-Gal staining of lacZ constructs (Fig. 4b). The corresponding IGF-I constructs stained more intensely with safranin $O$ than either control (Figs. $4 c$ and $5 a-c)$. In constructs from all groups, immunohistological evaluation demonstrated the absence of type I collagen (Fig. 5d-f) and the presence of type II collagen (Fig. 5g-i) and aggrecan (Fig. 5k-m). (a)

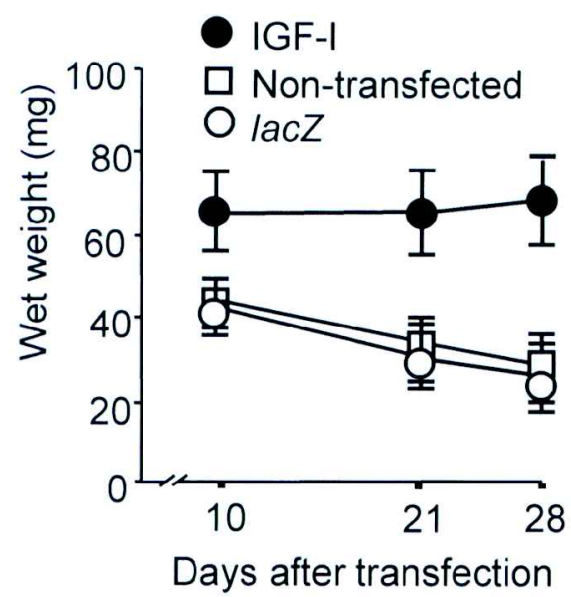

(b)

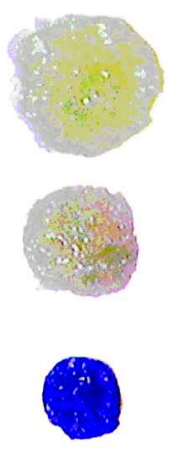

X-gal Safranin-O (c)

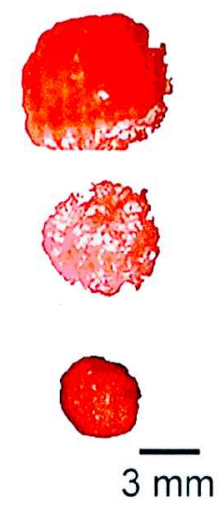

FIG. 4. Development of genetically modified cartilaginous constructs (a) Wet weights of engineered cartilaginous constructs based on chondrocytes transfected with lacZ (open circles), the human IGF-I (solid circles), or nontransfected chondrocytes (open squares) over 28 days of in vitro cultivation. The number of samples was $n=10$ for each group. (b) X-Gal staining and (c) safranin $\mathrm{O}$ staining of representative construct sections (top, IGF-I; middle, nontransfected; bottom, lacZ) on day 28 posttransfection. 
Table 1. Structural and Functional Parameters of Engineered Cartilage After 4 Weeks of Bioreactor Cultivation ${ }^{a}$

\begin{tabular}{|c|c|c|c|}
\hline \multirow{2}{*}{$\begin{array}{l}\text { Construct parameter } \\
\text { measured after } 4 \text { weeks of } \\
\text { bioreactor cultivation }\end{array}$} & \multicolumn{3}{|c|}{ Construct } \\
\hline & lacZ & $I G F-I$ & Nontransfected \\
\hline \multicolumn{4}{|l|}{ Construct structure } \\
\hline Wet weight (mg/construct) & $\begin{array}{c}26.5 \pm 2.1 \\
(n=10, p<0.001)\end{array}$ & $\begin{array}{c}67.7 \pm 10.8 \\
(n=10)\end{array}$ & $\begin{array}{c}29.0 \pm 8.5 \\
(n=10, p<0.001)\end{array}$ \\
\hline Dry weight (mg/construct) & $\begin{array}{c}2.2 \pm 0.4 \\
(n=10, p<0.001)\end{array}$ & $\begin{array}{l}5.8 \pm 1.1 \\
(n=10)\end{array}$ & $\begin{aligned} & 2.8 \pm 0.4 \\
(n= & 10, p<0.001)\end{aligned}$ \\
\hline Diameter $(\mathrm{mm})$ & $\begin{aligned} & 5.6 \pm 0.1 \\
(n= & 10, p<0.001)\end{aligned}$ & $\begin{array}{l}6.5 \pm 0.2 \\
(n=10)\end{array}$ & $\begin{aligned} & 5.3 \pm 0.2 \\
(n= & 10, p<0.001)\end{aligned}$ \\
\hline Water (\% wet weight) & $\begin{array}{c}92.5 \pm 1.0 \\
(n=6, p<0.05)\end{array}$ & $\begin{array}{c}91.3 \pm 0.9 \\
\quad(n=5)\end{array}$ & $\begin{array}{c}88.7 \pm 3.5 \\
(n=6, p>0.05)\end{array}$ \\
\hline DNA ( $\mu \mathrm{g} /$ construct $)$ & $\begin{array}{c}48.8 \pm 7.0 \\
(n=6, p=0.001)\end{array}$ & $\begin{aligned} 74.3 & \pm 11.5 \\
(n & =5)\end{aligned}$ & $\begin{array}{c}38.4 \pm 7.0 \\
(n=6, p=0.001)\end{array}$ \\
\hline $\begin{array}{l}\text { Glycosaminoglycans } \\
(\mu \mathrm{g} / \text { construct })\end{array}$ & $\begin{array}{c}96.3 \pm 15.3 \\
(n=6, p=0.001)\end{array}$ & $\begin{array}{c}1068.6 \pm 239.6 \\
(n=5)\end{array}$ & $\begin{array}{c}133.3 \pm 51.1 \\
(n=6, p<0.001)\end{array}$ \\
\hline $\begin{array}{l}\text { Glycosaminoglycans } \\
(\mu \mathrm{g} / \mu \mathrm{g} \text { DNA })\end{array}$ & $\begin{array}{c}2.0 \pm 0.2 \\
(n=6, p<0.001)\end{array}$ & $\begin{aligned} 14.3 & \pm 1.2 \\
(n & =5)\end{aligned}$ & $\begin{array}{c}3.4 \pm 0.9 \\
(n=6, p<0.001)\end{array}$ \\
\hline Collagen (mg/construct) & $\begin{array}{c}0.6 \pm 0.1 \\
(n=6, p<0.001)\end{array}$ & $\begin{array}{c}1.3 \pm 0.2 \\
(n=2)\end{array}$ & $\begin{array}{c}0.5 \pm 0.1 \\
(n=6, p<0.001)\end{array}$ \\
\hline Collagen $(\mu \mathrm{g} / \mu \mathrm{g}$ DNA $)$ & $\begin{array}{c}11.6 \pm 1.3 \\
(n=6, p<0.001)\end{array}$ & $\begin{array}{c}17.0 \pm 0.9 \\
\quad(n=5)\end{array}$ & $\begin{array}{c}14.1 \pm 1.9 \\
(n=6, p=0.015)\end{array}$ \\
\hline \multicolumn{4}{|l|}{ Construct fashion } \\
\hline $\begin{array}{l}{\left[{ }^{35} \mathrm{~S}\right] \text { Sulfate incorporation }} \\
(\mathrm{cpm} / \mu \mathrm{g} \text { DNA/16 hr) }\end{array}$ & $\begin{array}{c}2.3 \pm 0.6 \\
(n=6, p<0.001)\end{array}$ & $\begin{array}{l}9.4 \pm 1.0 \\
(n=5)\end{array}$ & $\begin{array}{c}3.8 \pm 0.9 \\
(n=6, p<0.001)\end{array}$ \\
\hline $\begin{array}{l}{\left[{ }^{3} \mathrm{H}\right] \text { Proline incorporation }} \\
(\mathrm{cpm} / \mu \mathrm{g} \text { DNA } / 16 \mathrm{hr})\end{array}$ & $\begin{array}{c}38.9 \pm 8.3 \\
(n=6, p<0.05)\end{array}$ & $\begin{array}{l}45.4 \pm 6.1 \\
\quad(n=5)\end{array}$ & $\begin{array}{c}43.6 \pm 7.1 \\
(n=6, p>0.05)\end{array}$ \\
\hline Glucose in medium $\left(\mathrm{mg} / \mathrm{cm}^{3}\right)$ & $\begin{array}{c}3.22 \pm 0.07 \\
(n=2, p>0.05)\end{array}$ & $\begin{array}{l}2.21 \pm 0.52 \\
\quad(n=2)\end{array}$ & $\begin{array}{c}3.11 \pm 0.20 \\
(n=2, p>0.05)\end{array}$ \\
\hline Lactate in medium $\left(\mathrm{mg} / \mathrm{cm}^{3}\right)$ & $\begin{array}{c}0.998 \pm 0.07 \\
(n=2, p>0.05)\end{array}$ & $\begin{array}{c}1.80 \pm 0.49 \\
(n=2)\end{array}$ & $\begin{array}{c}1.04 \pm 0.12 \\
(n=2, p>0.05)\end{array}$ \\
\hline Equilibrium modulus $(\mathrm{kPa})$ & $\begin{array}{c}35 \pm 33 \\
(n=3, p<0.05)\end{array}$ & $\begin{array}{c}126 \pm 52 \\
(n=4)\end{array}$ & $\begin{array}{c}30 \pm 4 \\
(n=3, p<0.03)\end{array}$ \\
\hline
\end{tabular}

${ }^{a}$ Values in parentheses indicate the number of samples per group followed by the $p$ value for comparing the respective control group with IGF-I constructs. Data represent averages \pm standard deviation.

IGF-I constructs contained increased amounts of DNA, glycosaminoglycans and collagen as compared with either control (Table 1), but the biochemical compositions remained subnormal for all groups. Importantly, the amount of glycosaminoglycansper unit DNA in IGF-I constructs $(14.3 \pm 1.2 \mu \mathrm{g} / \mu \mathrm{g})$ was markedly higher than for the corresponding constructs cultured in serumsupplemented medium (3.25 \pm 0.22 ; Vunjak-Novakovic et al., 1999), or native cartilage $(9.1 \pm 3.3$; Vunjak-Novakovic et al., 1999). The amount of collagen per unit DNA in IGF-I constructs $(17 \pm 0.9 \mu \mathrm{g} / \mu \mathrm{g})$ was also higher than for the corresponding constructs cultured in serum-supplemented medium (4.18 \pm 0.2 [Riesle et al., 1998; Vunjak-Novakovic et al., 1999]) or native cartilage (10.5 \pm 2.3 ; Vunjak-Novakovic et al., 1999).

\section{Biosynthetic activity and mechanical properties of engineered constructs}

Incorporation rate of $\left[{ }^{35} \mathrm{~S}\right]$ sulfate per microgram of DNA, an index of glycosaminoglycansynthesis, was markedly higher for
IGF-I constructs than for either nontransfected or lacZ constructs (Table 1). The incorporation rate of $\left[{ }^{3} \mathrm{H}\right]$ proline per microgram of DNA, an index of protein synthesis, was comparable for the three groups (Table 1). After 28 days of culture, the medium level of glucose was approximately $30 \%$ lower and the medium level of lactate was approximately $80 \%$ higher in bioreactors containing IGF-I constructs than in either control group (Table 1). IGF-I was not detected in the culture medium for any group at any time during cultivation.

The equilibrium modulus of IGF-I constructs was $126 \pm 52$ $\mathrm{kPa}$. This value was 4-fold higher than that measured for either control (Table 1), and slightly but not significantly lower than that measured for constructs cultured in medium supplemented with $10 \%$ serum (Vunjak-Novakovic et al., 1999). For comparison, the equilibrium moduli reported for bovine calf cartilage range from $270 \mathrm{kPa}$ for the articular surface (Chen et al., 2001) to approximately 700-900 kPa for the deep zone (Freed et al., 1997; Chen et al., 2001), with $470 \mathrm{kPa}$ reported as the mean homogeneous value (Mow and Ratcliffe, 1997; Chen et al., 2001). 

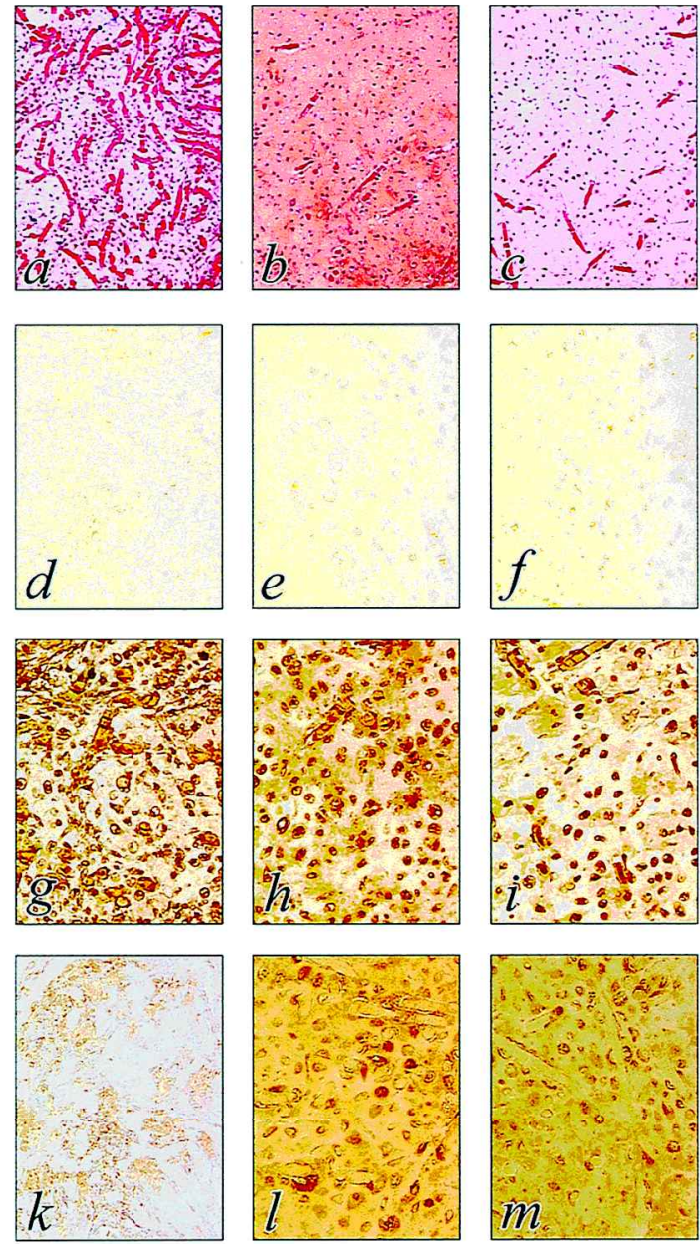

FIG. 5. Expression of cartilage-specific tissue markers. Representative histologic sections of genetically modified cartilaginous constructs on day 28 from the lac Z group (left), the IFG-I group (middle), and the nontransfected group (right) stained with safranin $\mathrm{O}(\mathbf{a}-\mathbf{c})$, a monoclonal anti-type I collagen antibody (d-f), a polyclonal anti-type II collagen antibody $(\mathbf{g}-\mathbf{i})$, or a monoclonal aggrecan antibody $(\mathbf{k}-\mathbf{m})$. Pictures were taken with the same photographic parameters, including the same light intensity. Original magnification(all images): $\times 200$.

\section{DISCUSSION}

Gene transfer of human IGF-I cDNA into articular chondrocytes markedly improved the structural and functional properties of tissue-engineered cartilage. Transgene expression was maintained over 28 days of in vitro cultivation followed by an additional 10 days either in vitro or in vivo. IGF-I gene transfer enhanced chondrogenesis in engineered constructs, as evidenced by significant increases in construct size and weight, biosynthesis and accumulation of cartilaginous tissue components, and mechanical properties. This is, to the best of our knowledge, the first report of the application of gene transfer to modulate the chondrogenesis in tissue-engineered cartilage. We utilized a model system based on genetically modified cells, three-dimensionalbiodegradable scaffolds, and a bioreactor de- signed to support tissue development from isolated cells under controlled environmental conditions.

The human IGF-I gene served as a model to demonstrate the potential benefits of gene transfer for tissue engineering. In these studies, we chose a lipid-based transfer system that has been previously shown to efficiently transfect articular chondrocytes (Madry and Trippel, 2000). To avoid phenotypic drift (von der Mark et al., 1977), the transfection protocol utilized a brief monolayer culture without passaging (Madry and Trippel, 2000; Madry et al., 2001a) The fibrous polyglycolic acid scaffolds were specifically designed for cartilage tissue engineering and have been well characterized in our previous studies (Freed et al., 1994). These scaffolds were dynamically seeded with cells, using a method that results in an essentially $100 \%$ yield of cell attachment, high initial cell density, and spatially uniform cell distribution (Vunjak-Novakovic et al., 1998). The resulting constructs were cultured in bioreactors in serum-free medium, under hydrodynamic conditions that were previously found optimal for in vitro chondrogenesis (Freed et al., 1998; Vunjak-Novakovic et al., 1999). We chose the model of subcutaneous implantation as a simple method to test for the maintenance of transgene expression in vivo (Vacanti et al., 1991; Freed et al., 1993; Krueger et al., 1997).

Constructs from all three groups were characterized as cartilaginous with respect to tissue morphology and composition of the extracellular matrix, including in particular the presence of glycosaminoglycans, aggrecan, and type II collagen, and the absence of type I collagen. The confined-compressionequilibrium modulus for IGF-I constructs was 4-fold higher than that for nontransfected and lacZ-transfected controls. This result is consistent with the respective biochemical construct compositions and previously reported structure-function relationships for engineered cartilage constructs (Vunjak-Novakovic et al., 1999) and native cartilage explants exposed to exogenous human IGFI (Sah et al., 1996). Further studies are needed to determine whether the observed effects are a result of sustained rather than early or transient expression of IGF-I, and to measure the fractions of transfected cells over the course of in vitro cultivation.

Gene transfer of human IGF-I increased the rate of $\left[{ }^{35} \mathrm{~S}\right] \mathrm{sul}-$ fate incorporationinto glycosaminoglycansafter 4 weeks in culture, but did not appear to increase the rate of $\left[{ }^{3} \mathrm{H}\right]$ proline incorporation into protein, suggesting that IGF-I differentially augmented synthesis of these matrix constituents at this time point. The observed anabolic effects of IGF-I on engineered cartilage are consistent with previously reported effects of IGFI on $\left[{ }^{3} \mathrm{H}\right]$ proline and $\left[{ }^{35} \mathrm{~S}\right]$ sulfate incorporation in articular chondrocytes (Trippel, 1995), articular cartilage explants (Sah et al., 1994), and articular cartilage in vivo (Nixon et al., 1999). For constructs engineered with nontransfected bovine articular chondrocytes, the incorporation rates of $\left[{ }^{35} \mathrm{~S}\right]$ sulfate and $\left[{ }^{3} \mathrm{H}\right]$ proline in 4-day constructs were comparable to those measured for freshly explanted cartilage, but decreased by approximately $40 \%$ over 6 weeks of cultivation (Freed et al., 1998), which may suggest that some of the effects of IGF-I were more pronounced at early stages of cultivation. Constructs and native cartilage contained similar amounts of $\left[{ }^{3} \mathrm{H}\right]$ proline relative to the total amount of incorporated ${ }^{3} \mathrm{H}$, indicating that proline hydroxylation did not appear to limit the rate of collagen synthesis (Freed et al., 1998). 
Constructs cultured in serum-free medium contained wet weight fractions of DNA, glycosaminoglycans, and collagen that were all below the corresponding values measured for constructs cultured in medium supplemented with $10 \%$ fetal bovine serum (Vunjak-Novakovic et al., 1999). IGF-I constructs contained amounts of glycosaminoglycansand total collagen per unit DNA that were markedly higher than in either control group (Table 1), constructs cultured in serum-supplemented medium, or freshly explanted native cartilage (Vunjak-Novakovic et al., 1999). Although IGF-I transfection substantially augmented the biochemical and biomechanical construct properties (Table 1), it did not bring them to normal levels measured for native cartilage.

The enhancement of the per-cell production of extracellular matrix components by the sustained, spatially defined overexpression of IGF-I may not have been fully utilized due to the low construct cellularity, which in turn may be caused by the lack of specific serum components in the serum-free culture medium. Studies have demonstrated that multiple factors, rather than a single growth factor at a time, are required to achieve rapid chondrogenesis in this model of cartilage tissue engineering (Gooch et al., 2001, 2002; Martin et al., 2001; Pei et al., 2001; Blunk et al., 2002). Future studies thus need to identify optimal combinations of genes that modulate and enhance in vitro chondrogenesis. Also, because the environment of the joint differs from that in a bioreactor and may contribute to the properties of the tissue, the application of such constructs to in vivo models may further modulate their properties.

The maintenance of transgene expression in engineered constructs in vivo forms a basis for further investigations of articular cartilage repair using genetically modified cartilaginous constructs. The long-term availability of the plasmid DNA vector within an engineered construct in an articular joint is a prerequisite for the stimulation of chondrogenesis over a prolonged period of time. For such applications, the cytomegalovirus (CMV) promoter-enhancer used in the present study may be replaced with regulatory elements that are tissue specific or responsive to physiological conditions (Kitamura and Kawachi, 1997).

In contrast to monolayer cultures of isolated, transfected chondrocytes (Madry and Trippel, 2000; Smith et al., 2000; Brower-Toland et al., 2001), the three-dimensional cartilaginous constructs analyzed in the present study did not release detectable amounts of IGF-I into the culture medium. This difference may reflect the retention of IGF-I within the constructs due to the presence of IGF-I-binding proteins, as has been shown for native articular cartilage (Sah et al., 1994). It is therefore possible that the observed effects are a result of the stimulus provided by an early and transient IGF-I expression. The absence of secreted IGF-I would be desirable in a clinical setting, in order to avoid systemic effects of the overexpressed growth factor.

One of the problems that currently limit ex vivo gene therapy of cartilaginous lesions is the loss of transplanted cells (O'Driscoll, 1998) and a decline in the transgene expression over time (Kang et al., 1997; Doherty et al., 1998). Also, the dense cartilaginous matrix was shown to limit the efficiency of direct in vivo gene transfer (Ikeda et al., 1998). Genetically modified cartilaginous constructs overexpressing a growth factor gene may be used as a tissue substitute that simultaneously provides a stimulus for repair. The transplantation of such con- structs may be advantageous compared with either gene therapy or tissue engineering alone.

In summary, gene transfer of a human IGF-I cDNA enhanced structural and functional properties of engineered cartilage. Gene expression was maintained throughout the duration of the study, over 4 weeks in vitro followed by an additional 10 days either in vitro or in vivo. The observed enhancement of chondrogenesis by spatially defined overexpression of human IGF-I suggests that cartilage tissue engineering based on genetically modified chondrocytes may be advantageous as compared with either gene transfer or tissue engineering alone. This new concept can potentially enhance the clinical utility of engineered cartilage, and provide physiologically relevant models for controlled studies of the effect of single genes on the regulation of chondrogenesis. Experiments of this kind could be extended to a variety of regulatory molecules in order to identify mechanisms that influence cartilage development. Further studies are needed to evaluate genetically modified cartilaginous constructs in clinically relevant models in vivo.

\section{ACKNOWLEDGMENTS}

We thank Li Zeng for help with the bioreactor studies, and Sue Kangiser for help with manuscript preparation. This work was supported by the Deutsche Akademie der Naturforscher Leopoldina (BMBF-LPD 9801-10; H.M.), the Deutsche Forschungsgemeinschaft (DFG MA 2363-1-1; H.M.), NASA grant NCC8-174 (L.E.F. and G.V.-N.), and NIH grants AR 31068 and AR 45749 (S.B.T.).

\section{REFERENCES}

BARAGI, V.M., RENKIEWICZ, R.R., JORDAN, H., BONADIO, J., HARTMAN, J.W., and ROESSLER, B.J. (1995). Transplantation of transduced chondrocytes protects articular cartilage from interleukin 1-induced extracellular matrix degradation. J. Clin. Invest. 96, 2454-2460.

BLUNK, T., SIEMINSKI, A.L., GOOCH, K.J., COURTER, D.L., HOLLANDER, A.P., NAHIR, A.M., LANGER, R., VUNJAK-NOVAKOVIC, G., and FREED, L.E. (2002). Differential effects of growth factors on tissue-engineered cartilage. Tissue Eng. 8, 73-84. BROWER-TOLAND, B.D., SAXER, R.A., GOODRICH, L.R., MI, Z., ROBBINS, P.D., EVANS, C.H., and NIXON, A.J. (2001). Direct adenovirus-mediated insulin-like growth factor I gene transfer enhances transplant chondrocyte function. Hum. Gene Ther. 12, 117 129.

BUCKWALTER, J.A., and MANKIN, H.J. (1998). Articular cartilage repair and transplantation. Arthritis Rheum. 41, 1331-1342.

CHEN, A.C., BAE, W.C., SCHINAGL, R.M., and SAH, R.L. (2001). Depth- and strain-dependent mechanical and electromechanical properties of full-thickness bovine articular cartilage in confined compression. J. Biomech. 34, 1-12.

DOHERTY, P.J., ZHANG, H., TREMBLAY, L., MANOLOPOULOS, V., and MARSHALL, K.W. (1998). Resurfacing of articular cartilage explants with genetically-modified human chondrocytes in vitro. Osteoarthr. Cartilage 6, 153-159.

EMING, S.A., SNOW, R.G., YARMUSH, M.L., and MORGAN, J.R. (1996). Targeted expression of insulin-like growth factor to human 
keratinocytes: Modification of the autocrine control of keratinocyte proliferation. J. Invest. Dermatol. 107, 113-120.

EVANS, C.H., and ROBBINS, P.D. (1999). Genetically augmented tissue engineering of the musculoskeletal system. Clin. Orthop. 367S, S410-S418.

FARNDALE, R.W., BUTTLER, D.J., and BARRETT, A.J. (1986). Improved quantitation and discrimination of sulphated glycosaminoglycans by the use of dimethylmethylene blue. Biochim. Biophys. Acta 883, 173-177.

FRANK, E.H., and GRODZINSKY, A.J. (1987). Cartilage electromechanics. II. A continuum model of cartilage electrokinetics and correlation with experiments. J. Biomech. 20, 629-639.

FREED, L.E., and VUNJAK-NOVAKOVIC, G. (2000). Tissue engineering bioreactors. In Principles of Tissue Engineering. R.P. Lanza, R. Langer, and J. Vacanti, eds. (Academic Press, San Diego, CA) pp. 143-156.

FREED, L.E., MARQUIS, J.C., NOHRIA, A., EMMANUAL, J., MIKOS, A.G., and LANGER, R. (1993). Neocartilage formation in vitro and in vivo using cells cultured on synthetic biodegradable polymers. J. Biomed. Mater. Res. 27, 11-23.

FREED, L.E., VUNJAK-NOVAKOVIC, G., BIRON, R., EAGLES, D., LESNOY, D., BARLOW, S., and LANGER, R. (1994). Biodegradable polymer scaffolds for tissue engineering. Biotechnology (NY) 12, 689-693.

FREED, L.E., LANGER, R., MARTIN, I., PELLIS, N., and VUNJAKNOVAKOVIC, G. (1997). Tissue engineering of cartilage in space. Proc. Natl. Acad. Sci. U.S.A. 94, 13885-13890.

FREED, L.E., HOLLANDER, A.P., MARTIN, I., BARRY, J.R., LANGER, R., and VUNJAK-NOVAKOVIC, G. (1998). Chondrogenesis in a cell-polymer-bioreactor system. Exp. Cell Res. 240, $58-65$.

GOOCH, K.J., BLUNK, T., COURTER, D.L., SIEMINSKI, A.L., BURSAC, P.M., VUNJAK-NOVAKOVIC, G., and FREED, L.E. (2001). IGF-I and mechanical environment interact to modulate engineered cartilage development. Biochem. Biophys. Res. Commun. 286, 909-915. GOOCH, K.J., BLUNK, T., COURTER, D.L., SIEMINSKI, A.L., VUNJAK-NOVAKOVIC, G., and FREED, L.E. (2002). Bone morphogenic proteins-2, -12 , and -13 modulate in vitro development of engineered cartilage. Tissue Eng. 8, 73-84.

HOLLANDER, A.P., HEATHFIELD, T.F., WEBBER, C., IWATA, Y., BOURNE, R., RORABECK, C., and POOLE, R.A. (1994). Increased damage to type II collagen in osteoarthritic articular cartilage detected by a new immunoassay. J. Clin. Invest. 93, 1722-1732. IKEDA, T., KUBO, T., ARAI, Y., NAKANISHI, T., KOBAYASHI, K., TAKAHASHI, K., IMANISHI, J., TAKIGAWA, M., and HIRASAWA, Y. (1998). Adenovirus mediated gene delivery to the joints of guinea pigs. J. Rheumatol. 25, 1666-1673.

KANG, R., MARUI, T., GHIVIZZANI, S.C., NITA, I.M., GEORGESCU, H.I., SUH, J.K., ROBBINS, P.D., and EVANS, C.H. (1997). Ex vivo gene transfer to chondrocytes in full-thickness articular cartilage defects: A feasibility study. Osteoarthr. Cartilage 5, 139-143.

KIM, Y.J., SAH, R.L., DOONG, J.Y.H., and GRODZINSKY, A.J. (1988). Fluorometric assay of DNA in cartilage explants using Hoechst 33258. Anal. Biochem. 174, 168-176.

KITAMURA, M., and KAWACHI, H. (1997). Creation of an in vivo cytosensor using engineered mesangial cells. Automatic sensing of glomerular inflammation controls transgene activity. J. Clin. Invest. 100, 1394-1399.

KRUEGER, G.G., JORGENSEN, C.M., PETERSEN, M.J., MANSBRIDGE, J.N., and MORGAN, J.R. (1997). Use of cloned genetically modified human fibroblasts to assess long-term survival in vivo. Hum. Gene Ther. 8, 523-532.

LANGER, R., and VACANTI, J.P. (1993). Tissue engineering. Science 260, 920-926.
MADRY, H., and TRIPPEL, S.B. (2000). Efficient lipid-mediated gene transfer to articular chondrocytes. Gene Ther. 7, 286-291.

MADRY, H., PADERA, R., SEIDEL, J., FREED, L.E., LANGER, R., TRIPPEL, S.B., and VUNJAK-NOVAKOVIC, G. (2001a). Tissue engineering of cartilage enhanced by the transfer of a human insulinlike growth factor-I gene. Trans. Orthop. Res. Soc. 26, 289.

MADRY, H., ZURAKOWSKI, D., and TRIPPEL, S.B. (2001b). Overexpression of human insulin-like growth factor-I promotes new tissue formation in an ex vivo model of articular chondrocyte transplantation. Gene Ther. 8, 1443-1449.

MARTIN, I., OBRADOVIC, B., FREED, L.E., and VUNJAK-NOVAKOVIC, G. (1999). A method for quantitative analysis of glycosaminoglycan distribution in cultured natural and engineered cartilage. Ann. Biomed. Eng. 27, 656-662.

MARTIN, I., SUETTERLIN, R., BASCHONG, W., HEBERER, M., VUNJAK-NOVAKOVIC, G., and FREED, L.E. (2001). Enhanced cartilage tissue engineering by sequential exposure of chondrocytes to FGF-2 during 2D expansion and BMP-2 during 3D cultivation. J. Cell. Biochem. 83, 121-128.

MOW, V.C., and RATCLIFFE, A. (1997). Structure and function of articular cartilage and meniscus. In Basic Orthopaedic Biomechanics. V.C. Mow and W.C. Hayes, eds. (Lippincott-Raven, Philadelphia) pp. 113-177.

NIXON, A.J., FORTIER, L.A., WILLIAMS, J., and MOHAMMED, H. (1999). Enhanced repair of extensive articular defects by insulinlike growth factor-I-laden fibrin composites. J. Orthop. Res. 17, 475-487.

O'DRISCOLL, S. (1998). The healing and regeneration of articular cartilage. J. Bone Joint Surg. Am. 80-A, 1795-1812.

PEI, M., SOLCHAGA, L.A., SEIDEL, J., ZENG, L., VUNJAKNOVAKOVIC, G., CAPLAN, A.I., and FREED, L.E. Bioreactors mediate the effectiveness of tissue engineering scaffolds. FASEB J. 10, 1096/fj.02-0083fje, published online August 7, 2002.

RIESLE, J., HOLLANDER, A.P., LANGER, R., FREED, L.E., and VUNJAK-NOVAKOVIC, G. (1998). Collagen in tissue-engineered cartilage: Types, structure and crosslinks. J. Cell. Biochem. 71, 313-327.

SAH, R.L., CHEN, A.C., GRODZINSKY, A.J., and TRIPPEL, S.B. (1994). Differential effects of bFGF and IGF-I on matrix metabolism in calf and adult bovine cartilage explants. Arch. Biochem. Biophys. 308, 137-147.

SAH, R.L., TRIPPEL, S.B., and GRODZINSKY, A.J. (1996). Differential effects of serum, insulin-like growth factor-I, and fibroblast growth factor- 2 on the maintenance of cartilage physical properties during long-term culture. J. Orthop. Res. 14, 44-52.

SALTZMAN, W.M. (1999). Delivering tissue regeneration. Nat. Biotechnol. 17, 534-535.

SMITH, P., SHULER, F.D., GEORGESCU, H.I., GHIVIZZANI, S.C., JOHNSTONE, B., NIYIBIZI, C., ROBBINS, P.D., and EVANS, C.H. (2000). Genetic enhancement of matrix synthesis by articular chondrocytes. J. Rheumatol. 43, 1156-1164.

TRIPPEL, S.B. (1995). Growth factor actions on articular cartilage. J. Rheumatol. 22, 129-132.

TRIPPEL, S.B. (1997). Growth factors as therapeutic agents. Instr. Course Lect. 46, 473-476.

TRIPPEL, S.B., VAN WYK, J.J., FOSTER, M.B., and SVOBODA, M.E. (1983). Characterization of a specific somatomedin-c receptor on isolated bovine growth plate chondrocytes. Endocrinology 112, 2128-2136.

VACANTI, C., LANGER, R., SCHLOO, B., and VACANTI, J.P. (1991). Synthetic biodegradable polymers seeded with chondrocytes provide a template for new cartilage formation in vivo. Plast. Reconstr. Surg. 88, 753-759.

VON DER MARK, K., GAUSS, V., VON DER MARK, H., and MULLER, P. (1977). Relationship between cell shape and type of 
collagen synthesised as chondrocytes lose their cartilage phenotype in culture. Nature 267, 531-532.

VUNJAK-NOVAKOVIC, G., OBRADOVIC, B., BURSAC, P., MARTIN, I., LANGER, R., and FREED, L.E. (1998). Dynamic cell seeding of polymer scaffolds for cartilage tissue engineering. Biotechnol. Prog. 14, 193-202.

VUNJAK-NOVAKOVIC, G., MARTIN, I., OBRADOVIC, B., TREPPO, S., GRODZINSKY, A.J., LANGER, R., and FREED, L.E. (1999). Bioreactor cultivation conditions modulate the composition and mechanical properties of tissue engineered cartilage. J. Orthop. Res. 17, 130-138.

WOESSNER, J.F. (1961). The determination of hydroxyproline in tissue and protein samples containing small proportions of this imino acid. Arch. Biochem. Biophys. 93, 440-447.
Address reprint requests to:

Dr. Gordana Vunjak-Novakovic Massachusetts Institute of Technology Harvard-MIT Division of Health Sciences and Technology MIT E25-330, 45 Carleton Street Cambridge, MA 02142

E-mail: gordana@mit.edu

Received for publication October 31, 2001; accepted after revision July 26, 2002.

Published online: August 13, 2002. 